\title{
PENGARUH LATIHAN HARVARD STEP UP TERHADAP PERUBAHAN VOLUME OKSIGEN MAKSIMAL PADA PEGAWAI KANTOR INDUK KANTOR KESEHATAN PELABUHAN KELAS I BATAM TAHUN 2019
}

\author{
Rizki Sari Utami Muchtar ${ }^{1 *}$, Rumdari $^{2}$ \\ ${ }^{1,2}$ Program Studi Ilmu Keperawatan \\ Sekolah Tinggi Ilmu Kesehatan Awal Bros Batam \\ Email korespondensi: sariutami0784@gmail.com
}

\begin{abstract}
ABSTRAK
Satu dari empat orang dewasa secara keseluruhan (28\% atau 1,4 milliar orang) secara fisik dinyatakan tidak aktif (Guthold et al., (2018). Rendahnya tingkat aktivitas fisik dapat mempengaruhi penurunan volume oksigen maksimal (VO2Max) yang digunakan sebagai parameter dalam menentukan kebugaran kardiorespiratori. Di Kantor Kesehatan Pelabuhan Kelas I Batam hanya 1/5 dari total pengawai yang memiliki kebugaran kardiorespirasi dengan kategori baik. Penelitian ini menggunakan metode Quasi experiment dengan rancangan penelitian One Group Time Series Design. Sampel penelitian ini sebanyak 17 responden.Intervensi yang dilakukan adalah dengan memberi perlakuan latihan fisik naik turun bangku terhadap responden. Hasil penelitian menunjukkan terjadi peningkatan yang signifikan $(\mathrm{P}<0.05)$ pada VO2Max responden. Penelitian ini membawa pada kesimpulan terdapat pengaruh latihan Harvard step up terhadap perubahan volume oksigen maksimal pada Pegawai induk Kantor kesehatan Pelabuhan Kelas I Batam.

Kata Kunci :Harvard step up, $\mathrm{VO}_{2} \mathrm{Max}$
\end{abstract}

\section{ABSTRACT}

One in four adults in total (28\% or 1.4 billion people) is physically inactive(Guthold et al. 2018a).The low level of activity due to sedentary lifestyles and increased technological development can affect the decrease in maximal oxygen volume ( $\left.\mathrm{VO}_{2} \mathrm{Max}\right)$ which is used as a parameter in determining cardiorespiratory fitness. At the Port Health Office Class I of Batam, only 1/5 of the total bodyguards have good cardiorespiratory fitness. This study used the Quasi experiment method with One Group Time Series Design. The sample of this study was 17 respondents. The treatment was to treat the physical exercise up and down the bench to the respondent. The results showed a significant increase $(P<0.05)$ in the respondent's $\mathrm{VO}_{2} \mathrm{Max}$. This study leads to the conclusion that there is an influence between the Harvard step up exercise on changes in the maximum volume of oxygen.

Keywords: Harvard step up, $\mathrm{VO}_{2} \mathrm{Max}$ 


\section{PENDAHULUAN}

Aktivitas fisik didefinisikan sebagai pergerakan atau perubahan tubuh yang dilakukan oleh otot rangka yang membutuhkan energi untuk peningkatan kebugaran dan kesehatan (Hoeger and Hoeger 2011). Seiring dengan perkembangan ilmu pengetahuan dan teknologi yang memberikan kemudahan bagi masyarakat, serta pola hidup masyarakat zaman sekarang yang cenderung sedenter atau tidak banyak melakukan aktivitas fisik memberi pengaruh yang kurang menguntungkan bagi kesehatan karena aktifitas olah fisik menjadi berkurang.

Menurut Guthold et al., (2018) menyatakan bahwa satu dari empat orang dewasa secara keseluruhan (28\% atau 1,4 milliar orang) secara fisik dinyatakan tidak aktif.. Sementara menurut Althoff $e t$ al., (2017) peneliti dari Universitas Stanford Amerika Serikat menunjukkan bahwa Singapura lebih baik ketimbang Indonesia dalam hal aktivitas fisik berjalan kaki.

Survei Healthy Living Index 2016 yang dilakukan perusahaan asuransi AIA di 15 negara Asia Pasifik, termasuk
Indonesia mengungkapkan bahwa 33\% orang tua di Indonesia mengatakan anakanak mereka kurang berolah raga. Sementara laporan Hasil Riset Kesehatan Dasar (Riskesdas) tahun 2013 menunjukkan proporsi aktivitas fisik penduduk yang kurang aktif di Indonesia sebesar $26.1 \%$, sedangkan dari seluruh provinsi di Indonesia terdapat 22 provinsi yang aktivitas penduduknya tergolong kurang aktif dengan proporsi diatas ratarata nasional termasuk di provinsi Kepulauan Riau sebesar 33.5\%(Kemenkes RI 2013).

Latihan fisik yang dapat digunakan untuk meningkatkan $\mathrm{VO}_{2} \mathrm{Max}$ adalah latihan yang dapat meningkatkan transport oksigen. Salah satunya adalah dengan melakukan Harvard Step Up. Dari penelitian yang telah dilakukan oleh Anggraeni(2013) latihan naik turun bangku memberikan pengaruh yang signifikan terhadap peningkatan kebugaran jasmani pada siswa kelas $\mathrm{X}$ SMA N I Seputih Agung. Latihan Harvard Step Up atau latihan naik turun bangku dengan pemberian intensitas waktu yang bertambah secara bertahap dapat menyebabkan perubahan yang 
bermakna pada penurunan tekanan darah serta penurunan denyut nadi pada 26 siswa Sekolah Sepakbola Tugu Muda Semarang(Putra and Basyar 2015).

Dari hasil studi pendahuluan didapatkan laporan data hasil tes kebugaran pada pegawai KKP Kelas I Batam dengan menggunakan Metode Rockport pada bulan Januari 2018, dengan hasil $\mathrm{VO}_{2}$ Maxpegawai perempuan dengankategori : kurang 15.5\%, Cukup $57.7 \%$, Baik $17.8 \%$; pegawai laki - laki dengan kategori : kurang $18.2 \%$, Cukup $51 \%$, Baik $21.8 \%$. Dari data tersebut menunjukkan proporsi pegawai yang $\mathrm{VO}_{2} \mathrm{Max}$ dalam kategori baik hanyasebesar $19.8 \%$, artinya hanya $1 / 5$ dari total pengawai yang memiliki kebugaran kardiorespirasi dengan kategori baik (KKP Kelas I Batam 2018).

\section{LANDASAN TEORI}

Salah satu cara pengukuran tingkat ketahanan kardiorespirasi adalah dengan mengukur $\mathrm{VO}_{2}$ Maks atau volume maksimal oksigen yang diproses oleh tubuh manusia pada saat melakukan kegiatan yang intensif. Orang yang memiliki daya tahan kardiorespirasi rendah, ia harus bekerja lebih keras untuk memenuhi kebutuhan oksigen(Hoeger and Hoeger 2011).

Beberapa faktor yang mempengaruhi $\mathrm{VO}_{2} \mathrm{Max}$ antara lain :(Sutriono, Purwoko, and Hardian 2014)

1) Umur

a) Daya tahan jantung dan pembuluh darah

b) Kekuatan Otot

2) Jenis Kelamin

3) Suhu

4) Model dan Intensitas Latihan Fisik

5) Hereditas

6) Komposisi tubuh

7) Kardiovaskuler

8) Pulmonal

9) Kadar Hemoglobin dalam Sel Darah Merah

Pengertian dari latihan adalah suatu aktivitas olahraga yang dilakukan secara rutin dan teratur dalam jangka waktu yang lama, dengan peningkatan beban secara progresif sesuai dengan keperluan masingmasing individu dengan tujuan membentuk dan mengembangkan fungsi fisiologis dan psikologis. Prinsip dari latihan sesungguhnya adalah memberikan stress atau tekanan fisik secara teratur, sistematis, berkesinambungan, 
sehingga dapat meningkatkan kemampuan di dalam kerja(Putra and Basyar 2015).

Salah satu latihan daya tahan dapat dilakukan dengan latihan naik turun bangku.Latihan naik turun bangku merupakan perkembangan dari Harvard Step Up. Harvard step up test diciptakan oleh Brouha di Laboratorium OlahragaHarvard. Harvard Step Up dilakukan pada anak-anak sampai dewasa muda, laki-laki maupun perempuan (Lacy 2015).

Keuntungan dari Harvard Step Up sangat mudah dimengerti dan mudah untuk dilakukan serta dapat dimodifikasi sesuai partisipan. Step up test sangat sering digunakan untuk kesehatan kardiovaskuler dan respiratori. Tingkat kerja ditentukan oleh tinggi dan frekuensi latihan, dimana total beban latihan tergantung dari banyaknya latihan dari periode latihan. Semua latihan step up cocok untuk latihan masal dan kelompok, performa latihan berdasarkan deyut nadi dan tekanan darah pada saat fase istirahat. Step up test dapat memberikan beberapa manfaat yang baik pada kebugaran kardiovaskuler dan respirasi.(Leung et al. 2013b)

\section{Kerangka Teori}

\section{Faktor yang mempengaruhi}

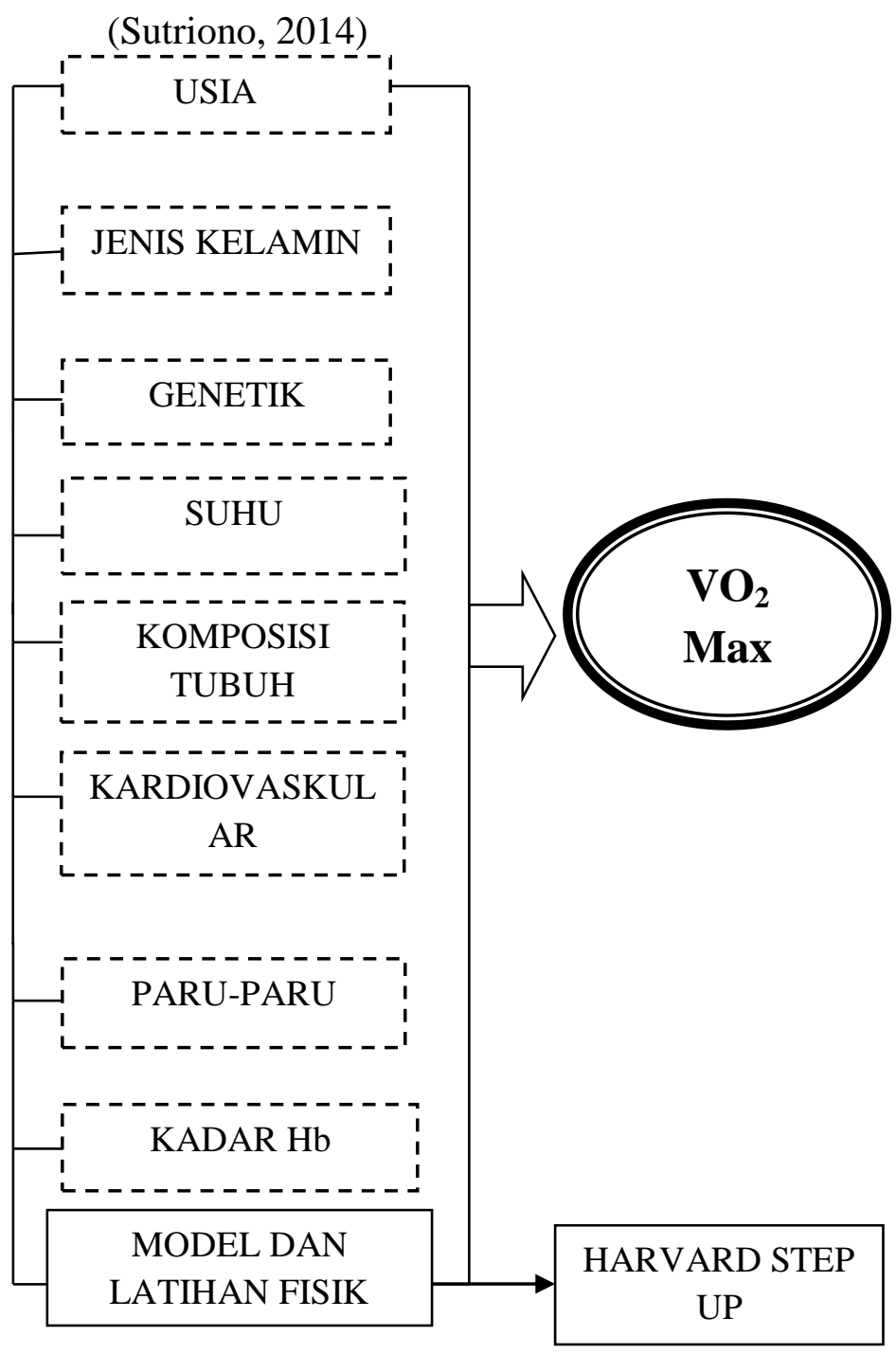

Ket :

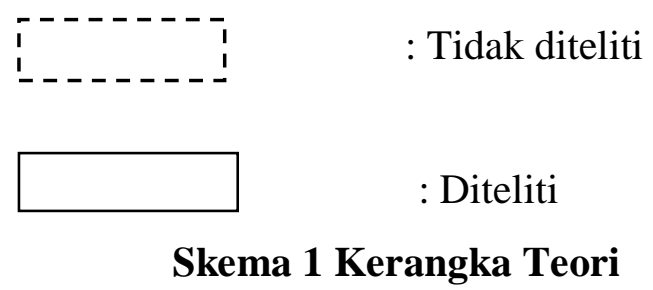




\section{METODE PENELITIAN}

Jenis penelitian ini adalah penelitian kuantitatif dengan menggunakan metode penelitian Quasi Eksperiment (Eksperiment Semu) dan menggunakan rancangan penelitian One GroupTime Series Design dengan mengintervensi satu kelompok saja tanpa kelompok pembanding. Efektifitas perlakuan dinilai dengan cara membandingkan hasil $\mathrm{VO}_{2}$ Max awal dengan hasilVO $\mathrm{O}_{2}$ Max seminggu, duaminggu, dan tigaminggu setelah diberikan perlakuan (treatment), Responden akan diberikan perlakuan dengan latihan Harvard Step Upselama 4 kali/ minggu selama 3 minggu.

\section{HASIL PENELITIAN}

\section{Karakteristik Responden}

Subyek penelitian ini adalah pegawai yang berada di kantor induk KKP Kelas I Batam sebanyak 17 orang. Treatment (perlakuan) dilakukan 12 kali dengan frekwensi latihan 4 (empat) kali dalam satu minggu, yaitu pada hari Senin, Rabu, Kamis, Jumat.

\section{Univariat}

Berdasarkan hasil penelitian yang telah dilakukan pada bulan Januari 2019 dengan jumlah responden 17 orang didapat hasil :

a. Distribusi Rata-rata Volume Oksigen Maksimal ( $\left.\mathrm{VO}_{2} \quad \mathrm{Max}\right)$ Sebelum Latihan Harvard Step Up (Naik Turun Bangku)

Tabel 4.1 Distribusi Rata-rata VO2 Max Sebelum latihan Harvard Step Up

\begin{tabular}{lc}
\hline \multicolumn{1}{c}{ Variabel } & $\begin{array}{c}\text { Mean VO2 Max } \\
(\mathbf{m l} / \mathbf{k g} / \mathbf{m i n})\end{array}$ \\
\hline Awal (Sebelum & \\
Latihan Harvard & 75.6 \\
Step Up) & \\
\hline
\end{tabular}

Hasil analisa pada tabel 4.5 diatas menunjukkan bahwa nilai $\begin{array}{llll}\text { rata-rata } & \mathrm{VO}_{2} & \text { Max } & \text { sebelum }\end{array}$ dilakukan latihan Harvard Step Up adalah 75,6 $\mathrm{ml} / \mathrm{kg} / \mathrm{min}$, dengan kategori cukup.

b. Distribusi Rata-rata Volume Oksigen Maksimal ( $\left.\mathrm{VO}_{2} \quad \mathrm{Max}\right)$ Setelah Latihan Harvard Step Up (Naik Turun Bangku).

Tabel 4.2 Distribusi Rata-rata VO2 Max Setelah latihan Harvard Step Up

\begin{tabular}{lc}
\hline \multicolumn{1}{c}{ Variabel } & $\begin{array}{c}\text { Mean VO2 Max } \\
(\mathbf{m l} / \mathbf{k g} / \mathbf{m i n})\end{array}$ \\
\hline $\begin{array}{l}\text { Seminggu Setelah Latihan } \\
\text { Harvard Step Up } \\
\text { Duaminggu Setelah }\end{array}$ & 80.4 \\
$\begin{array}{l}\text { Latihan Harvard Step Up } \\
\text { Tigaminggu Setelah } \\
\text { Latihan Harvard Step Up }\end{array}$ & 84.8 \\
\hline
\end{tabular}


Hasil analisa pada tabel 4.5 menunjukkan bahwa nilai rata-rata kenaikan $\mathrm{VO}_{2}$ Max seminggu setelah dilakukan latihan Harvard Step Up adalah $80.4 \mathrm{ml} / \mathrm{kg} / \mathrm{min}$ dengan kategori baik, sedangkan nilai ratarata kenaikan $\mathrm{VO}_{2}$ Max Duaminggu Setelah latihan Harvard Step Up adalah $84.8 \mathrm{ml} / \mathrm{kg} / \mathrm{min}$ dengan kategori baik dan nilai rata-rata kenaikan $\mathrm{VO}_{2}$ Max Tigaminggu Setelah latihan Harvard Step Up adalah $91.2 \mathrm{ml} / \mathrm{kg} / \mathrm{min}$ dengan kategori sangat baik.

\section{Bivariat}

Tabel 4.3 Perbedaan Rata-rata Kenaikan VO2 Max Terhadap Pengaruh latihan Harvard Step Up Setelah diberikan perlakuan.

\begin{tabular}{lcccc} 
Variabel & $\mathrm{N}$ & Mean & $\mathrm{SD}$ & $\begin{array}{c}p \text { - } \\
\text { Value }\end{array}$ \\
\hline Sebelum & 17 & 75.56 & 19.58 & \\
$\begin{array}{l}\text { Seminggu } \\
\text { Setelah }\end{array}$ & 17 & 80.4 & 15.86 & $\mathbf{0 . 0 7}$ \\
\hline $\begin{array}{l}\text { Sebelum } \\
\text { Dua minggu } \\
\text { setelah }\end{array}$ & 17 & 75.56 & 19.58 & \\
\hline $\begin{array}{l}\text { Sebelum } \\
\text { Tiga minggu } \\
\text { setelah }\end{array}$ & 17 & 84.8 & 13.71 & $\mathbf{0 . 0 2}$ \\
\hline & 17 & 75.56 & 19.58 & \\
\hline & & 91.2 & 15.43 & $\mathbf{0 . 0 0}$ \\
\end{tabular}

Berdasarkan tabel 4.6 rata-rata $\mathrm{VO}_{2}$ Max Responden sebelum diberikan latihan Harvard Step Up adalah $75.6 \mathrm{ml} / \mathrm{kg} / \mathrm{min}$ dengan standar deviasi 19,58, seminggu setelah diberikan perlakuan berupa latihan Harvard Step Up didapat rata-rata kenaikan $\mathrm{VO}_{2}$ Max sebesar $80.4 \mathrm{ml} / \mathrm{kg} / \mathrm{min}$ dengan standar deviasi 15.86 dengan hasil p-Value 0.07 ( $p$-Value $>0.05)$, hal ini berarti bahwa tidak ada perbedaan yang signifikan antara rata-rata kenaikan $\mathrm{VO}_{2}$ Max sebelum dan seminggu setelah latihan Harvard Step Up.

Hasil dua minggu setelah latihan didapat rata-rata kenaikan $\mathrm{VO}_{2}$ Max sebesar $84.8 \mathrm{ml} / \mathrm{kg} / \mathrm{min}$ dengan standar deviasi 13.71, dengan hasil p-Value 0.02 (p-Value $<0.05)$, hal ini berarti bahwa ada perbedaan yang signifikan antara rata-rata kenaikan $\mathrm{VO}_{2} \mathrm{Max}$ sebelum dan duaminggu setelah latihan Harvard Step Up.

Hasil tiga minggu setelah diberikan perlakuan berupa latihan Harvard Step Up didapat rata-rata kenaikan $\mathrm{VO}_{2}$ Max sebesar 91.2 
$\mathrm{ml} / \mathrm{kg} / \mathrm{min}$ dengan standar deviasi 15.43, dengan hasil $p$-Value 0.00 ( $p$ Value < 0.05), hal ini berarti bahwa ada perbedaan yang signifikan antara rata-rata kenaikan $\mathrm{VO}_{2}$ Max sebelum dan Tigaminggu setelah latihan Harvard Step Up.

\section{PEMBAHASAN}

\section{Analis Univariat}

a. Nilai $\mathrm{VO}_{2}$ Max Sebelum Latihan Harvard Step Up (Naik Turun Bangku)

Usia mempunyai hubungan penting terhadap $\mathrm{VO}_{2}$ Max. menurut Omega D (2017) dalam buku karangan Macmurray dan Ondrak 2008 nilai $\mathrm{VO}_{2}$ Max akan turun secara normal sejalan dengan bertambahnya umur yang dapat disebabkan oleh perubahan komposisi tubuh dan gaya hidup orang dewasa yang tidak aktif. Penurunan kebugaran pada pertambahan usia yang disertai dengan penurunan status kesehatan salah satunya ditandai dengan perubahan fisiologis pada jantung. Perubahan tersebut meliputi penurunan curah jantung istirahat dan maksimum, penurunan nadi maksimum, peningkatan waktu kontraksi dan rileksasi otot jantung, peningkatan kekuatan otot jantung saat fase diastole, penurunan jumlah sel otot fungsional dan akumulasi pigmen dalam sel otot jantung.(Prabowo, 2014). Perubahan tersebut akan mempengaruhi penurunan $\mathrm{VO}_{2} \mathrm{Max}$.

IMT memiliki kaitan yang besar dengan nilai $\mathrm{VO}_{2}$ Max yang dihasilkan. Menurut (Guthold et al. 2018b) semakin besar IMT maka semakin sedikit nilai $\mathrm{VO}_{2}$ Max. Hal demikian juga dikatakan pada penelitian (Vittala et al. 2016), berat badan berlebih memiliki makna berbanding terbalik dengan daya tahan kardiorespiratori. Setiap penambahan $1 \mathrm{~kg} / \mathrm{m}^{2}$ indeks massa tubuh akan menurunkan nilai $\mathrm{VO}_{2}$ Max sebesar $1,348 \mathrm{ml} / \mathrm{kg} / \mathrm{mnt} . \quad V O_{2} \quad$ Max merupakan parameter dari daya tahan kardiorespiratori, semakin besar berat badan maka semakin sedikit oksigen yang mampu dikonsumsi sehingga menyebabkan penurunan daya tahan kardiorespirasi.

Berdasarkan hasil penelitian jumlah aktivitas dan latihan memiliki hubungan dengan $\mathrm{VO}_{2}$ Max.Seseorang yang kurang melakukan aktivitas fisik, aliran balik ke jantung lebih sedikit dibandingkan pada orang yang melakukan aktivitas fisik secara teratur.Begitu juga dengan pengambilan jumlah oksigen yang masuk ke tubuh jauh lebih sedikit dibandingkan dengan orang yang melakukan aktivitas fisik.Jumlah 
oksigen yang sedikit menyebabkan kerusakan pada system organ yang membutuhkan oksigen. Hal tersebut yang akan mempengaruhi penurunan daya tahan kardiorespiratori (Vittala et al. 2016).

Dari beberapa teori yang sudah dijelaskan diatas maka peneliti dapat menyimpulkan bahwa $\mathrm{VO}_{2}$ Max akan mengalami penurunan seiring dengan bertambahnya usia dan dapat dipengaruhi oleh faktor lainnya seperti faktor genetic, jenis kelamin, suhu, komposisi tubuh, kardiovaskular, paru-paru, kadar Hemoglobin dalam darah, dan juga latihan fisik sehari hari.

b. Nilai $\mathrm{VO}_{2}$ Max Sesudah Latihan Harvard Step Up (Naik Turun Bangku)

Berdasarkan hasil penelitian pada tabel 4.5, yang telah peneliti lakukan, dalam pengolahan data menunjukkan bahwa dari 17 responden didapat nilai rata-rata $\mathrm{VO}_{2} \operatorname{Max}$ seminggu sesudah latihan Harvard Step Up adalah sebesar $80.4 \mathrm{ml} / \mathrm{kg} / \mathrm{min}$ dengan kategori baik, sedangkan nilai rata-rata $\mathrm{VO}_{2}$ Max duaminggu sesudah latihan Harvard Step Up adalah sebesar $84.8 \mathrm{ml} / \mathrm{kg} / \mathrm{min}$ dengan kategori baik, dan nilai rata-rata $\mathrm{VO}_{2}$ Max tigaminggu sesudah latihan Harvard
Step Up adalah sebesar $91.17 \mathrm{ml} / \mathrm{kg} / \mathrm{min}$ dengan kategori sangat baik.

Berdasarkan hasil peningkatan nilai $\mathrm{VO}_{2}$ Max pada pemberian latihan fisik berupa latihan Harvard Step Up ada hubungannya dengan faktor internal dan eksternal. Menurut Salehi, dkk (2014) faktor-faktor tersebut bergantung pada banyaknya oksigen atmosfer, kandungan mitokondria, kapasitas difusi, paru, curah jantung, kemampuan transfer oksigen oleh pembuluh darah dan karakteristik otot individu. Selain itu usia, jenis kelamin, dan tingkat aktivitas fisik juga penting dalam peningkatan $\mathrm{VO}_{2} \mathrm{Max}$.

Hasil penelitian yang dilakukan Anggraeni (2013) dengan judul "Pengaruh Latihan Naik Turun Bangku dan Naik Turun Tangga Terhadap Peningkatan Kebugaran Jasmani" berdasarkan hasil perlakuan latihan fisik Naik Turun Bangku dan Naik Turun Tangga yang diberikan, terdapat perubahan nilai $\mathrm{VO}_{2} \quad$ Maxyang signifikan yang berpengaruh terhadap naiknya kebugaran jasmani. Peningkatan $\mathrm{VO}_{2}$ Max tersebut diakibatkan oleh peningkatan stroke volume dan peningkatan ekstrasi oksigen oleh kontraksi otot yang tercermin dalam peningkatan kapasitas difusi dan pertukaran 
gas, sehingga kebutuhan darah pada organ yang membutuhkan terpenuhi.

Hasil penelitian lain juga mengatakan hal yang serupa. Pada penelitian Rai, dkk (2015) dengan judul "A Study On Cardiovascular Fitness of sedentary Collage students" mengatakan bahwa terjadi peningkatan $\mathrm{VO}_{2}$ Max akibat latihan fisik yang menyebabkan kemampuan jantung dalam memompa darah dan peningkatan eksatrasi oksigen, kedua hal tersebut merupakan faktor penting dalam peningkatan $\mathrm{VO}_{2}$ Maxselain itu, intensitas dan durasi latihan fisik juga sangat mempengarhi kinerja jantung serta hasil $\mathrm{VO}_{2}$ Max. Sedangkan hasil penelitian yang didapatkan dari Scribbans, dkk (2016), dengan judul "The Effect Trainning Intensity On $\mathrm{VO}_{2}$ MaxIn Young Healty adults: A Meta Regression And Meta Analysis" juga mengatakan hal yang sama bahwa dengan latihan fisik yang dilakukan secara terus-menerus dan intens dapat meningkatkan $\mathrm{VO}_{2} \quad$ Maxx setara $80-92,5 \%$ nilai $\mathrm{VO}_{2} \mathrm{Max}$.

Dari beberapa teori yang sudah dijelaskan diatas dan dari hasil penelitian yang telah dilakukan maka peneliti menyimpulkan bahwa dapat terjadi peningkatan VO2 Max akibat latihan fisik
Harvard Step Up yang disebabkan karena pada saat latihan, paru-paru juga akan bekerja secara aktif meningkatkan pertukaran gas $\left(\mathrm{O}_{2}\right.$ dan $\left.\mathrm{CO}_{2}\right)$ yang melintasi membran alveoli-kapiler. Oksigen akan menembus membran alveoli-kapiler dan diambil atau diikat oleh hemogoblin dan dibawa ke jantung. Peningkatan pertukaran gas yang diakibatkan kontraksi otot selama latihan lebih banyak mengkonsumsi oksigen dalam jumlah besar dan menghasilkan karbon dioksida dalam jumlah besar menyebabkan permukaan alveolar membesar.Sehingga proses pengiriman oksigen ke jaringan yang dibutuhkan akan meningkat, sistem kardiorespirasi harus bekerja lebih keras untuk mensuplai oksigen yang cukup agar aktivitas tetap berjalan sehingga saat sistem kardiorespirasi lebih efisien dalam mensuplai oksigen maka tingkat ketahanan kardiorespirasi akan meningkat dan tubuh akan lebih tahan terhadap rasa lelah.

\section{Analis Bivariat}

c. Pengaruh Latihan Harvard Step Up Terhadap Perubahan Volume Oksigen Maksimal $\left(\mathrm{VO}_{2}\right.$ Max) Sebelum dan Setelah Perlakuan.

Berdasarkan hasil analisa bivariat, dengan menggunakan Repeat Measures Anova Test perbandingan nilai rata-rata 
sebelum dan seminggu setelah dilakukan latihan Harvard Step $U p$ didapat nilai $P$ Value $=0.07>0.05$ yang berarti Ha ditolak dan Ho diterima, artinya tidak ada pengaruh yang signifikan dari peningkatan nilai ratarata $\mathrm{VO}_{2}$ Max seminggu setelah latihan fisik Harvard Step Up. Sementara perbandingan nilai rata-rata sebelum dan dua minggu setelah dilakukan latihan Harvard Step Up didapatnilai $P$-Value $=0.02<0.05$ yang berarti Ho ditolak dan Ha diterima yang artinya ada pengaruh yang signifikan dari peningkatan nilai rata-rata $\mathrm{VO}_{2}$ Max duaminggu setelah latihan fisik Harvard Step $U p$ dengan nilai rata-rata peningkatan $\mathrm{VO}_{2}$ Max sebesar $9.3 \mathrm{ml} / \mathrm{kg} / \mathrm{min}$. Dan perbandingan nilai rata-rata sebelum dan tiga minggu setelah dilakukan latihan Harvard Step Up didapatnilainilai $P$-Value $=0.00<$ 0.05 yang berarti Ho ditolak dan Ha diterima yang artinya ada pengaruh yang signifikan dari peningkatan nilai rata-rata $V_{2}$ Max tigaminggu setelah latihan fisik Harvard Step $U p$ pada Pegawai Kantor Induk Kantor Kesehatan Pelabuhan Kelas I Batam, dengan nilai rata-rata peningkatan $\mathrm{VO}_{2}$ Maxsebesar $15.6 \mathrm{ml} / \mathrm{kg} / \mathrm{min}$ stelah tiga minggu perlakuan.Perubahan $\mathrm{VO}_{2} \mathrm{Max}$ setelah latihan Harvard Step Up ini disebabkan oleh respon kardiovaskular terhadap aktivitas fisik yaitu dengan meningkatkan cardiac output. Peningkatan ini disebabkan oleh peningkatan isi sekuncup jantung maupun heart rate yang dapat mencapai sekitar 95\% dari tingkat maksimalnya. Karena pemakaian oksigen oleh tubuh tidak dapat lebih dari kecepatan sistem kardiovaskuler menghantarkan oksigen ke jaringan, maka dapat dikatakan bahwa sistem kardiovaskular, dapat membatasi nilai $\mathrm{VO}_{2} \operatorname{Max}$ (Uliyandri 2009).

Selain itu pada penelitian ini juga didominasi oleh responden perempuan sebesar 64,7\%. Nilai rata-rata $\mathrm{VO}_{2}$ Max yang awalnya cenderung lebih rendah dari nilai rata-rata $\mathrm{VO}_{2}$ Max laki-laki setelah perlakuan terjadi peningkatan yang signifikan,hal ini membuktikan bahwa latihan fisik Harvard Step Updapat meningkatkan nilai $\mathrm{VO}_{2}$ Maxpada perempuan. Hal ini sejalan dengan penelitian yang dilakukan oleh Omega D (2017) dalam judul penelitiannya "Pengaruh Latihan Fisik Terhadap Peningkatan $\mathrm{VO}_{2}$ Max Pada Remaja Putri Universitas 'Aisyiyah Yogyakarta" bahwa ada pengaruh latihan fisik terhadap peningkatan $\mathrm{VO}_{2} \mathrm{Max}$ pada remaja putri Universitas Aisyiyah Yogyakarta di kelompok perlakuan,hal ini disebabkan karena kekuatan dan massa otot 
pada perempuan menjadi lebih besar setelah diberikan latihan karena kontraksi otot yang besar akan lebih banyak mengkonsumsi oksigen dalam jumlah besar sehingga proses pengiriman oksigen ke jaringan yang dibutuhkan akan meningkat.

Responden pada penelitian ini mayoritas berumur 25 - 35 tahun, nilai $\mathrm{VO}_{2}$ Maks mencapai puncak pada usia 18-20 tahun, sehingga jika responden mayoritas berumur 25-45 tahun nilai $V_{2}$ Max akan berkurang secara bertahap (1\% per tahun) setelah usia 25 tahun. Pada orang yang aktif secara fisik, penurunan terjadi $5 \%$ per dekade, sedangkan pada orang dengan gaya hidup sedenter, penurunan $\mathrm{VO}_{2}$ maks mencapai 10\% per dekade (Strijk, 2010). Setelah diberikan perlakuan, nilai $\mathrm{VO}_{2} \mathrm{Max}$ mengalami peningkatan yang signifikan, hal ini membuktikan bahwa latihan fisik Harvard Step Up dapat meningkatkan nilai $V_{2}$ Max. Hal ini sejalan dengan penelitian yang dilakukan oleh Adhidharma (2014) yang berjudul "Karakteristik Tingkat Kebugaran Kardiorespirasi Siswa Kelas 6 SD di Desa Mengawiti Tahun 2014" bahwa ada pengaruh aktivitas fisik yang dilakukan siswa kelas 6 SD yang memiliki berbagai hambatan dalam keoptimalan kebugaran jasmani.

Dalam Penelitian ini juga di dominasi oleh responden yang memiliki berat badan lebih (Obesitas grade I) setelah dilakukan perlakuan terjadi peningkatan nilai $\mathrm{VO}_{2}$ Maks. Hal ini sejalan dengan penelitian Budiarto (2012) yang berjudul "Hubungan Antara Indeks Massa Tubuh Dan Nilai Volume Oksigen Maksimal ( $\mathrm{VO}_{2} \mathrm{Maks}$ ) Pada Mahasiswa Apikes Citra Medika Surakarta"didapatkan adanya hubungan IMT dengan volume oksigen maksimal pada mahasiswa Apikes Citra Medika Surakarta, hal ini dikarenakan bahwa semakin tinggi IMT, maka menurunkan volume oksigen maksimal. $\mathrm{VO}_{2}$ maks adalah kadar oksigen tertinggi yang dapat dikonsumsi selama latihan, yang menggambarkan fungsi paru, kardiovaskular, dan hematologi serta mekanisme oksidasi dari otot yang aktif selama proses latihan. Selain itu $\mathrm{VO}_{2}$ maks dapat digunakan sebagai tolak ukur dalam latihan aerobik dengan $\mathrm{VO}_{2}$ maks menentukan kebugaran kardiorespirasi

Dari beberapa teori yang telah dijelaskan dan dari hasil penelitian sebelumnya, maka dapat disimpulkan bahwa kebugaran kardiorespiratori yang kurang 
optimal yang diketahui dengan cara mengukur volume oksigen maksimal pada seseorang dapat ditingkatkan dengan cara melakukan latihan fisik Harvard Step $U p$ (naik turun bangku), karena latihan fisik Harvard Step Up yang dilakukan secara rutin selama 4 (empat) kali seminggu dalam jangka waktu 3 (tiga) minggu dapat meningkatkan kemampuan jantung, paruparu, pembuluh darah, dan komponen darah dalam menyuplai oksigen yang cukup, sehingga tingkat kebugaran kardiorespiratori akan meningkat dan seseorang tidak akan merasa cepat lelah saat beraktivitas.

\section{Implikasi Penelitian}

Hasil penelitian ini menunjukkan adanya pengaruh latihan fisik Harvard Step Up terhadap perubahan volume oksigen maksimal, oleh karena itu penelitian ini memberikan alternatif salah satu latihan fisik bagi praktek keperawatan, serta perawat komunitas dalam memberikan pelayanan kesehatan. Sebagaimana dengan hasil penelitian yang didapat, penelitian ini juga memberikan ilmu baru terkait upaya dalam meningkatkan kebugaran kardiorespiratori seseorang melalui latihan fisik Harvard
Step Up bagi pendidikan keperawatan dan memberikan sarana baru memperoleh pengetahuan seputar latihan fisik Harvard Step Upbagi peneliti berikutnya.

\section{Kemudahan dan Keterbatasan}

\section{Penelitian}

1. Kemudahan

a. Peneliti tidak mengalami kesulitan dalam melakukan kontrak dan melakukan hubungan dengan para Responden, Responden kooperatif.

b. Sudah ada penelitian sebelumnya terkait dengan Harvard Step Up dan tentang upaya peningkatan $V_{2}$ Max, jadi Peneliti tidak mengalami kesulitan dalam mencari sumber terkait untuk membandingkan dan menyempurnakan penelitian sebelumnya.

2. Keterbatasan

Penelitian telah dilaksanakan semaksimal mungkin, namun tidak terlepas dari keterbatasanketerbatasan yang membuat hasil penelitian mempunyai kekurangan, 
adapun keterbatasan peneliti sebagai berikut:

a. Terbatasnya jumlah dana, waktu dan jumlah Pegawai yang ada di Kantor Induk KKP Kelas I Batam yang aktif latihan sehingga populasi yang digunakan dalam penelitian masih tergolong kecil

b. Perlakuan responden tidak bisa dilaksanakan secara bersamasama (harus satu persatu) untuk menghindari kesalahan perhitungan nilai, jadi memakan waktu cukup lama

c. Dari 25 responden yang lolos kriteria inklusi, hanya 17 responden yang dapat mengikuti program latihan sampai akhir. 5 (lima) responden mengundurkan diri karena mengalami kram otot di awal latihan dan tidak mau melanjutkan program latihan selanjutnya, 3 (tiga) responden gugur karena dinas luar kota.

d. Peneliti sulit dalam mengontrol faktor-faktor lain yang mungkin mempengaruhi hasil test, seperti : waktu istirahat, kondisi tubuh, faktor psikologi, dan sebagainya. e. Sampel tidak diasramakan, sehingga kemungkinan ada yang berlatih sendiri diluar treatment.

\section{KESIMPULAN DAN SARAN}

\section{Kesimpulan}

Berdasarkan hasil peneltian dan uraian pembahasan dapat disimpulkan bahwa:

1. Nilai rata-rata $\mathrm{VO}_{2}$ Maxsebelumperlakuan latihan fisik Harvard Step Upadalah 75,6 $\mathrm{ml} / \mathrm{kg} / \mathrm{min}$ dengan kategori cukup.

2. Nilai rata-rata perubahan $\mathrm{VO}_{2}$ Maxsetelah perlakuan latihan fisik Harvard Step Up adalah91.2 $\mathrm{ml} / \mathrm{kg} / \mathrm{min}$ dengan kategori sangat baik.

3. Perbedaan rata-rata $\mathrm{VO}_{2}$ Max sebelum dan setelah perlakuan latihan fisik Harvard Step $U p$ dengan nilai $p$-value $0.00(p<0.05)$ yang berarti terdapat perbedaan yang signifikan, artinya ada pengaruh latihan Harvard Step $U p$ terhadap perubahan $V_{2}$ Max pada Pegawai Kantor Induk.

\section{Saran}

Berdasarkan kesimpulan penelitian diatas, ada beberapa saran yang dapat disampaikan untuk dapat membantu meningkatkan kesehatan dan mencegah resiko timbulnya masalah penyakit, saran tersebut antara lain :

1. Praktek Keperawatan 
a. Kepala Kantor Kesehatan Pelabuhan Kelas I Batam

Disarankan untuk dapat mengaktifkan program latihan Harvard Step Up untuk dilakukan setiap hari sekali di sela sela kerja untuk dapat meningkatkan dan mempertahankan kebugaran jasmani para Pegawai serta sebagai salah satu alternatif olah gerak fisik untuk merealisasikan upaya preventif penyakit tidak menular (PTM) dalam program gerakan masyarakat hidup sehat (Germas)

b. Responden

Diharapkan untuk terus melanjutkan kegiatan latihan fisik Harvard Step Up untuk meningkatkan dan mempertahankan kebugaran kardiorespiratori.

2. Pendidikan Kesehatan

Penelitian ini dapat dijadikan sebagai tambahan ilmu khususnya pada bidang keperawatan komunitas tentang keefektifan latihan Harvard Step Up terhadap peningkatan volume oksigen maksimal (kebugaran kardiorespiratori) pada masyarakat atau kelompok tertentu maupun institusi kesehatan sebagai lahan pratek.

3. Peneliti Selanjutnya
Hasil penelitian ini menambah wawasan dan pengetahuan mengenai latihan fisik serta volume oksigen maksimal. Penelitian lanjutan perlu dilakukan untuk menyempurnakan pembahasan dan aplikasi latihan Harvard Step Up, adapun penambahan untuk peneliti selanjutnya yaitu

a. Disarankan untuk dapat mengontrol durasi latihan dan latihan fisik lainnya yang dilakukan responden diluar penelitian.

b. Menambah jangka latihan yang lebih lama untuk penelitian selanjutnya

\section{DAFTAR PUSTAKA}

Adhidharma, Nyoman Chandra. 2014.

"Karakteristik Tingkat Kebugaran

Kardiorespirasi Siswa Kelas 6 SD Di Desa

Mengawiti Tahun 2014.” E-Jurnal Medika

5(5): 1-7.

Althoff, Tim et al. 2017. "Large-Scale Physical Activity Data Reveal Worldwide Activity Inequality." Nature 547(7663): 336-39. http://www.nature.com/doifinder/10.1038/na ture23018 (December 4, 2018).

Andrade, Carlos Henrique Silva de, Reinaldo Giovanini Cianci, Carla Malaguti, and 
Simone Dal Corso. 2012. "The Use of Step

Tests for the Assessment of Exercise

Capacity in Healthy Subjects and in Patients

with Chronic Lung Disease." Jornal

brasileiro de pneumologia : publicacao

oficial da Sociedade Brasileira de

Pneumologia e Tisilogia 38(1): 116-24.

http://www.ncbi.nlm.nih.gov/pubmed/22407

048 (December 4, 2018).

Anggraeni, Agatha Dian. 2013. "PENGARUH

LATIHAN NAIK TURUN TANGGA

TERHADAP PENINGKATAN

KEBUGARAN JASMANI."

Budiarto, Rahmat A. 2012. "Hubungan Antara

Indeks Massa Tubuh Dan Nilai Volume

Oksigen Maksimal (Vo2maks) Pada

Mahasiswa Apikes Citra Medika Surakarta.”

Fakultas Kedokteran Universitas

Muhammadiyah Surakarta.

Dharmesh, Parmar, and Modh Nikita. 2013.

"Study of Physical Fitness Iindex With

Modified Harvard Step Test in Medical

Students." International Journal of Science

and Research (IJSR) 4(7): 1215-17.

Erwinanto, Oleh Dion. 2017. "Hubungan Antara

Tingkat Aktivitas Fisik Dengan Kebugaran

Jasmani Siswa Smk Muhammadiyah 1

Wates.": 1-11.
Ghomin, Saudail. 2017. "Hubungan Antara Kebugaran (Six Minute Walking Test)

Dengan Aktivias Fisik, Status Gizi, Asupan

Nutrisi, Status Kesehatan Dan Perilaku

Merokok Pada Calon Jamaah Haji Di Desa

Mojosari." Universitas Islam Negeri Syarif

Hidayatullah.

Guthold, Regina, Gretchen A Stevens, Leanne M Riley, and Fiona C Bull. 2018a. "Worldwide Trends in Insufficient Physical Activity from 2001 to 2016: A Pooled Analysis of 358 Population-Based Surveys with 1.9 Million

Participants." The Lancet Global Health 6(10): e1077-86.

https://linkinghub.elsevier.com/retrieve/pii/S $2214109 X 18303577$.

_. 2018b. "Worldwide Trends in Insufficient Physical Activity from 2001 to 2016: A Pooled Analysis of 358 Population-

Based Surveys with 1.9 Million

Participants." The Lancet Global Health 6(10): e1077-86.

https://linkinghub.elsevier.com/retrieve/pii/S 2214109X18303577 (December 4, 2018).

Hoeger, Wener WK, and Sharon A Hoeger. 2011. Cengage Learning; edition (2011-0101)(1656) Principles and Labs for Fitness and Wellness by Wener W.K. Hoeger (2011- 
01-01): Wener W.K. Hoeger; Sharon A.

Hoeger: Amazon.Com: Books.

Inaz. 2014. "Penjaskes: Harvard Step."

www.penjaskesolga.blogspot.com.

http://penjaskesolga.blogspot.com/2014/12/h

arvard-step.html (November 5, 2018).

Julianto. 2015. "Pengaruh Bermain Tali Skipping

Dan Jalan Cepat Terhadap Peningkatan

Kesegaran Krdiorespirasi Peserta

Ekstrakurikuler Voli Di SMP Belinyu."

Universitas Negeri Yogyakarta.

Kemenkes RI. 2013. “RISET KESEHATAN

DASAR 2013." Jakarta: Badan Penelitian

dan Pengembangan Kesehatan Departemen

Kesehatan Republik Indonesia (Penyakit

Menular): 103.

http://www.academia.edu/download/362354

91/Laporan_riskesdas_2010.pdf.

_. 2016. "Pemerintah Canangkan Gerakan

Masyarakat Hidup Sehat (GERMAS).”

www.depkes.go.id.

http://www.depkes.go.id/article/print/161116

00003/pemerintah-canangkan-gerakan-

masyarakat-hidup-sehat-germas-.html

(October 4, 2018).

KKP Kelas I Batam. 2018. Laporan Hasil Test

Kebugaran Pegawai KKP Kelas I Batam.
Batam.

Lacy, Alan C. 2015. Measurement and

Evaluation in Physical Education and

Exercise Science, 7th Edition | Pearson. 7th

ed. ed. Illionois State University.

https://www.pearson.com/us/higher-

education/program/Lacy-Measurement-and-

Evaluation-in-Physical-Education-and-

Exercise-Science-7th-

Edition/PGM116513.html.

Leung, Ting-Kai et al. 2013a. "Physiological

Effects of Bioceramic Material: Harvard

Step, Resting Metabolic Rate and Treadmill

Running Assessments." The Chinese Journal

of Physiology 56(6): 334-40.

http://www.ncbi.nlm.nih.gov/pubmed/24495

180 (December 4, 2018).

- 2013b. "Physiological Effects of

Bioceramic Material: Harvard Step, Resting

Metabolic Rate and Treadmill Running

Assessments." The Chinese Journal of

Physiology 56(6): 334-40.

http://www.ncbi.nlm.nih.gov/pubmed/24495

180 (December 4, 2018).

Lim, Jeong Uk et al. 2017. "Comparison of

World Health Organization and Asia-Pacific

Body Mass Index Classifications in COPD

Patients." International Journal of Chronic 
Obstructive Pulmonary Disease 12: 2465.

http://www.ncbi.nlm.nih.gov/pubmed/28860

741 (December 5, 2018).

Nonce, Nonce. 2015. "Survey Tingkat Kesegaran Jasmani Siswa Kelas V Sekolah Dasar Negeri 25 Palu Kecamatan Palu Timur." Tadulako Journal Sport Sciences And Physical Education 2(8).

http://jurnal.untad.ac.id/jurnal/index.php/PJ KR/article/view/3489 (December 4, 2018).

Nugraha, Harry. 2018. “AIA Dan David

Beckham Mengajak Masyarakat Indonesia Untuk Hidup Lebih Sehat, Lebih Lama, Lebih Baik." http://www.aia-financial.co.id. http://www.aia-financial.co.id/id/aboutaia/info-media/press-releases/2018/aia-dandavid-beckham-mengajak-masyarakatindonesia-untuk-hidup-lebih-sehat-lebihlama-lebih-baik-2018.html (October 4, 2018).

Omega D, Selly. 2017. "Pengaruh Latihan Fisik Terhadap Peningkatan VO2Max." Universitas Aisyiah Yogjakarta.

Prabowo, Sigit Bangun. 2013. "Tingkat

Kebugaran Jasmani Anggota Klub Jantung Sehat Mugas Kota Semarang Tahun 2013." Universitas Negeri Semarang.
Prativi, Gilang Okta, Soegiyanto, and Sutardji. 2013. "Pengaruh Aktivitas Olahraga Terhadap Kebugaran Jasmani." Journal of Sport Sciences and Fitness 2(3): 56-61.

Prentice, William E. 2012. Get Fit, Stay Fit. McGraw-Hill Companies, Inc.

Purnama. 2016. "Tatacara Melakukan Pengujian Harvard Step Test Untuk Menentukan Tingkat Kebugaran Jantung Paru Permainan Bola Voli.” www.volimaniak.com: 1. https://www.volimaniak.com/2016/02/tataca ra-melakukan-pengujian-harvard-steptest.html (December 4, 2018).

Putra, Adhitya Wicaksana, and Edwin Basyar. 2015. 4 Media Medika Indonesiana PENGARUH LATIHAN STEP UP TERHADAP PENURUNAN TEKANAN DARAH PADA SISWA SEKOLAH SEPAK BOLA TUGU MUDA SEMARANG USIA 1214 TAHUN.

Salsabila, Annisa Falihati, Tanjung Ayu Sumekar, and Yuswo Supatmo. 2017. "Kebugaran Jasmani Dan Skor Rpe Pada Latihan Tes." 6(2): 306-11.

Sharkey, Brian J. 2011. KEBUGARAN DAN KESEHATAN (Terjemahan Dari Fitness and 
Health). ed. Terjemahan Eri Desmarini N.

Jakarta: Rajagrafindo Persada.

Sharma, Priyanka et al. 2018. "Assessment of

Level of Physical Fitness and Level of

Mental Stress in Exercising and Non-

Exercising Physiotherapy Students." : 12-

16.

Silaban, NF. 2014. "Profil Kebugaran Jasmani

Siswa Yang Mengikuti Ekstrakurikuler

Sepak Bola Sma Negeri 1 Tiga Lingga

Tahun 2014." UNIMED.

Sunarno, Agung, and RD Sihombing. 2011.

Metode Penelitian Keolahragaan. Surakarta:

Yuma Pustaka.

Sutriono, Sutriono, Yosef Purwoko, and Hardian

Hardian. 2014. "Pengaruh Pemberian Air

Minum Beroksigen Dibanding Dengan Air

Minum Biasa Terhadap Nilai Vo2Max Dan

Tekanan Darah.” Jurnal Kedokteran

Diponegoro 3(1).

https://ejournal3.undip.ac.id/index.php/medi

co/article/view/7973.
Uliyandri, Adhikarmika. 2009. "Pengaruh

Latihan Fisik Terprogram Terhadap

Perubahan Nilai Konsumsi Oksigen

Maksimal (VO2 Max) Pada Siswi Sekolah

Bola Voli Tugu Muda Semarang Usia 11-13

Tahun." FK Undip 27(1): xv-xv.

Vittala, G Nurmawan, Silakarma, and Sutadarma. 2016. "Pengaruh Jantung Sehat Terhadap

Peningkatan Kardiorespirasi Pada

Mahasiswa Dengan Kelebihan Berat

Badan." Universitas Udayana.

WHO. 2014. "Physical Activity." World Health

Organization (February).

http://www.nap.edu/catalog/21760.

. 2018. "NCDs | Launch of New Global

Estimates on Levels of Physical Activity in

Adults." WHO.

http://www.who.int/ncds/prevention/physica 1-activity/lancet-global-health-insufficientphysical-activity-2001-2016/en/ (December 4, 2018). 